\title{
Molecular characterization and Antibiotic resistance profiles of Escherichia coli extended-spectrum $\beta$-lactamases producer strains isolated from urine samples in Benin
}

\author{
Wassiyath Mousse, PhD \\ Haziz Sina, PhD
}

Laboratoire de Biologie et de Typage Moléculaire en Microbiologie, Faculté des Sciences et Techniques/Université d'Abomey-Calavi, Cotonou, Benin

\section{Mamadou Wele, PhD}

Université des Sciences et Techniques de Bamako (USTTB), Bamako, Mali

Nicodeme Chabi, PhD

Ecole Polytechnique d'Abomey-Calavi, (EPAC) - Benin

Durand Dah Nouvlessounon, PhD

Farid T. Bade, M.Sc.

Faridath Chabi, M.Sc.

Laboratoire de Biologie et de Typage Moléculaire en Microbiologie, Faculté des Sciences et Techniques/Université d'Abomey-Calavi, Cotonou, Benin

\section{Severin Anagonou, PhD}

Faculté des Sciences et Santé, Université d'Abomey-Calavi. ISBA, Champ de foire, Cotonou, Benin Adolphe Adjanohoun, PhD

Centre de Recherches Agricoles Sud/ Institut National des Recherches Agricoles du Bénin. Niaouli, Benin

\section{Lamine Baba-Moussa, PhD}

Laboratoire de Biologie et de Typage Moléculaire en Microbiologie, Faculté des Sciences et Techniques/Université d'Abomey-Calavi, Cotonou, Benin

Doi: 10.19044/esj.2018.v14n30p323 URL:http://dx.doi.org/10.19044/esj.2018.v14n30p323

\begin{abstract}
Urinary tract infections are the second common reason of medical consultations and antibiotics prescription. Escherichia coli is known to cause most urinary tract infections. The aim of this study was to characterize and determine the antibiotic resistance profile of $E$. coli extended-spectrum $\beta$ lactamases (ESBL) producer strains isolated from urine samples. The urine samples collected came from hospitalized and non-hospitalized patient
\end{abstract}


referred to Hubert Koutoukou Manga (HKM), National and University Hospital Center (Cotonou, Benin). The resistance to antibiotics was determined according to the disk diffusion method. The production of penicillinase and ESBLs was researched respectively by the acidimetric test and double disk synergy method. The presences of genes encoding $\beta$ lactamases were detected by Polymerase Chain Reaction (PCR). Our data revealed that $60 \%$ of $E$. coli strains (101) were isolated from female patients. Also, $69.31 \%$ of the strains were isolated from non-hospitalized patients. The high resistance levels were recorded with amoxicillin (96.04\%) and amoxicillin + clavulanic acid (66.34\%). Twenty percent $(20 \%)$ of strains were ESBLs. Among ESBLs strains, 70\% comes from non-hospitalized patients. Eighty percent of $E$. coli strains produced penicillinase among which $25 \%$ were ESBL producers. All the ESBL producers strains carried bla

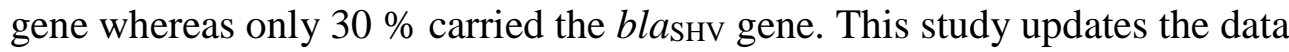
on the prevalence to antibiotic resistance of $E$. coli ESBL producers strains for better management of urinary tract infections.

Keywords: Urinary Infections, Antibiotic, Resistance, ESBL, Benin

\section{Introduction}

Infectious diseases are world widespread causing over 50000 deaths daily (Ahmad et Beg, 2001). Many bacteria, such as Escherichia coli, were involved in those infections. E. coli, part of the human commensal Flore, is known to be the first bacteria to colonize humans gut. Indeed, E. coli belonging to the family of Enterobacteriaceae is an important opportunist human pathogen associated with infections such as urinary tract, surgical site, skin, soft tissues, bacteremia, and pneumonia infections (Pitout, 2012; Carvalho et al., 2012). Among those infections, urinary tract infections are considered as a public health problem (Fatna et al., 2009) because the urine of healthy person must be exempt of any microorganism (Foxman, 2002). Thus, the identification of the cause and severity of the urinary tract infection are usually established through biochemical and microbiological analysis of urines. Urinary tract infections having E. coli as etiological agent are common infections with an estimated annual global incidence of at least 250 million cases (Chauhan et al., 2015).

To treat infections induced by $E$. coli strains, antibiotics such as those $\beta$-lactam groups are currently used. This group includes the penicillin's cephalosporins, carbapenems, clavams and monobactams (Singleton, 1999). Often, the $\beta$-lactam ring is cleaved by a bacterial enzyme named $\beta$-lactamase (Edwards et Greenwood, 1992). But population density, uncontrolled use of antibiotics, lack of clean water supply and lack of proper treatment for sewage has resulted in the selection of multidrug resistant bacterial strains. This 
becomes a serious challenge for drug prescription in infectious diseases management (Carlet et al., 2012). For example, in developed countries, it was reported that the economic and human damage caused by antibiotic-resistance is increasing at an alarming rate (Bush et al., 2011). Infections with multidrug-resistant organisms have linked with poorer clinical outcomes and prolonged hospitalization on average compared to infectionss with susceptible pathogens (Maina et al., 2017).

In hospital area, the extended spectrum $\beta$-lactamases (ESBL) strains are one of the barriers to efficient treatment of $E$. coli infections (Lucet et al., 1996). The selection of E. coli strains producing ESBL is increased by the large prescription of third cephalosporins generation. We should notice that ESBL are enzymes that confer resistance to aztreonam, cefotaxime, ceftazidime, and like to relate oxyimino- $\beta$-lactams as well as other penicillin and cephalosporins (Bush et al., 1995). The most common mechanism of the resistance to $\beta$-lactam antibiotics is the production of $\beta$-lactamase. The genes encoding for $\beta$-lactam production are generally harbored by plasmids (Paterson et Bonomo, 2005). Although there are several type genes encoding for ESBL, the first and most founded mutants are bla TEM $_{\text {and }}$ bla SHV $_{\text {(Bois et }}$ al., 1995; Medeiros, 1997). The mutants with those genes can deflect the oxyimino group and then induce the resistant to all oxyimino-cephalosporins (except $\alpha$-methoxy cephalosporins) (Livermore et Woodford, 2006).

In Benin, few papers report on the urinary tract infection focusing on the $E$. coli strains characterization. To fill this gap, it will be useful to update E. coli ESBLs information. Thus, the aim of this study was to characterize and determine the antibiotic resistance profile of $E$. coli ESBL producer strains isolated from urine samples.

\section{Material and methods:}

Samples collection

A total of 979 urines samples were collected from both hospitalized patient and non- hospitalized patient referred to National and University Hospital Center Hubert Koutoukou Manga (Cotonou, Benin). The urine samples collected from January to April 2015. Sample of patient hospitalized in the Hospital Center was considered as hospitalized patient. If the patient wasn't hospitalized in Hospital Center, he was considered as no hospitalized patient. Among the urine samples sent to the Microbiology laboratory of CNHU for analysis, only those that were analyzed for the purpose of diagnosing urinary tract infection and whose Escherichia coli strains were isolated mainly were taken into account in this study. 


\section{Isolation and identification of $\boldsymbol{E}$. coli strains}

The collected samples were cultured on Eosin Methylene Blue (EMB) agar (Oxoid, UK) media. On the EMB agar, E. coli gives purple colonies in the dark center, semi-convex 2 to $3 \mathrm{~mm}$ in diameter and sometimes have a metallic sheen After overnight incubation in aerobic condition (18-24 h) at 37 ${ }^{\circ} \mathrm{C}$, the colonies suspected to be $E$. coli were picked and purified for $E$. coli identification according to standard biochemical tests (gram coloration, oxidase test and citrate utilization) (Riegel et al., 2005), before a confirmation with API 20E (Bio Mérieux, France) gallery.

\section{Antibiotics resistance of isolated strains}

The susceptibility of the isolated E. coli strains to 16 antimicrobial agents was evaluated by the disk diffusion method on Mueller-Hinton agar according to the French Society for Microbiology guidelines (CASFM, 2015).

The antimicrobial agents (BioMérieux, France) used in this study are: amoxicillin $(30 \mu \mathrm{g})$, amoxicillin/clavulanic acid $(20 / 10 \mu \mathrm{g})$, cefoxitin $(30 \mu \mathrm{g})$, cefuroxime $(30 \mu \mathrm{g})$, cefotaxime $(30 \mu \mathrm{g})$, ceftriaxone $(30 \mu \mathrm{g})$, imipenem $(10$ $\mu \mathrm{g})$, gentamicin $(15 \mu \mathrm{g})$, netilmicin $(10 \mu \mathrm{g})$, chloramphenicol (30 $\mu \mathrm{g})$, nalidixic acid, $(30 \mu \mathrm{g})$, norfloxacin $(5 \mu \mathrm{g})$, ofloxacin $(5 \mu \mathrm{g})$, ciprofloxacin (5 $\mu \mathrm{g})$, trimethoprim/sulfamethoxazole $(1.25 / 23.75 \mu \mathrm{g})$ and nitrofurantoin $(300$ $\mu \mathrm{g})$. These antibiotics have been chosen because they are the most used in the treatment of urinary tract infections au Benin.

\section{Detection of Penicillinase production}

The production of penicillinase was researched on all E. coli strains isolated according to tube acidimetric method as describe by Catlin in 1975 . Benzyl-penicillin (600 mg) was diluted in $400 \mu \mathrm{L}$ of distilled water before adding $300 \mu \mathrm{L}$ of aqueous phenol red solution $(1 \%, \mathrm{w} / \mathrm{v})$. The $\mathrm{pH}$ of the precedent solution was adjusted to 8 with $\mathrm{NaOH}$ solution $(1 \mathrm{M})$. The final 1 $\mathrm{mL}$ reaction volume was composed of a young $E$. coli colonies in suspension and about $150 \mu \mathrm{l}$ of benzyl-penicillin solution. The E. coli ATCC 25922 strains was used as a control. The yellow color apparition within one hour indicates penicillinase production.

\section{Phenotypic detection of Extended Spectrum $\beta$-Lactamase (ESBL) production}

The production of Extended Spectrum $\beta$-Lactamase was performed on the all isolated $E$. coli strains by the double disk synergy test as described by Jarlier et al. (1988). Agar Muller Hinton medium was seeded with bacteria suspension $\left(10^{6} \mathrm{CFU} / \mathrm{mL}\right)$. Amoxicillin + clavulanic acid disk was deposited in the Centre of agar. About $20 \mathrm{~mm}$ away from two disks external, cefotaxime 
and ceftazidime disks were added. After 18-24 h of incubation at $37{ }^{\circ} \mathrm{C}$, the presence of ESBLs was indicated by a champagne cork aspect between the central and the external disks.

\section{Genomic detection of genes coding to Extended Spectrum $\beta$-Lactamase (ESBL) production}

Detection of the ESBL genes encoding blaTEM and blasHV was performed with total DNA. The DNA template was prepared from freshly cultured bacterial isolates by suspending 2-3 colonies in $500 \mu \mathrm{L}$ of molecular grade water and then vortexed to get a uniform suspension. Bacterial cells were lysed by heating at $95{ }^{\circ} \mathrm{C}$ for $10 \mathrm{~min}$. Cellular debris was removed by centrifugation at 12,000 rpm for $2 \mathrm{~min}$ and the supernatant was directly used as DNA template to amplify blaTEM and blasHV genes by Polymerase Chain Reaction (PCR). The PCR amplification was carried out in volume of $30 \mu \mathrm{l}$ containing $5 \mu \mathrm{L}$ of DNA, $0.5 \mu \mathrm{M}$ of each primer (F and R), $1.5 \mathrm{mM} \mathrm{MgCl}_{2}$, $250 \mu \mathrm{M}$ dNTPs, 1X PCR buffer (Invitrogen) and 1U Taq DNA polymerase (Invitrogen). The primer sequences and the generated fragments are presented in the table 1.

Table 1: Primers used to research for genes $b l a_{T E M}$ and $b l a_{S H V}$.

\begin{tabular}{|l|c|c|c|}
\hline Genes & Names & Sequences & Size (base pairs) \\
\hline \multirow{2}{*}{$b^{\prime} a_{T E M}$} & TEM OT-1-F & 5'-TTGGGTGCACGAGTGGGTTA-3' & \multirow{2}{*}{465} \\
\cline { 2 - 3 } & TEM OT-2-R & 5'-TAATTGTTGCCGGGAAGCTA-3' & \\
\hline \multirow{2}{*}{$b_{\text {s }}{ }_{S H V}$} & SHV A & 5'-CACTCAAGGATGTATTGTG-3' & \multirow{2}{*}{885} \\
\cline { 2 - 3 } & SHV B & 5'-TTAGCGTTGCCAGTGCTCG-3' & \\
\hline
\end{tabular}

Amplification was carried out on a DNA thermal cycler (Multigene Labnet International, Inc.) as follows: i- for bla $a_{T E M}$ (initial denaturation $94{ }^{\circ} \mathrm{C}$ for $5 \mathrm{~min}$ followed by 30 cycles $94{ }^{\circ} \mathrm{C}$ for $30 \mathrm{~s}, 52^{\circ} \mathrm{C}$ for $30 \mathrm{sec}, 72{ }^{\circ} \mathrm{C}$ for 1 min and a final elongation step $10 \mathrm{~min}$ at $72{ }^{\circ} \mathrm{C}$ ) and ii- for bla $a_{S H V}$ (initial denaturation was performed at $96{ }^{\circ} \mathrm{C}$ for $5 \mathrm{~min}, 30$ cycles of $96{ }^{\circ} \mathrm{C}$ for $15 \mathrm{~s}$, $50{ }^{\circ} \mathrm{C}$ for $15 \mathrm{sec}, 72{ }^{\circ} \mathrm{C}$ for $1 \mathrm{~min}$ and a final elongation step $10 \mathrm{~min}$ at $72{ }^{\circ} \mathrm{C}$ ). The amplicons were visualized by a trans-illuminator (Euromedex, Mundosheim, France) after electrophoresis at $150 \mathrm{~V}$ for $30 \mathrm{~min}$ on an agarose gel $(1.2 \%, \mathrm{w} / \mathrm{v})$ containing ethidium bromide.

\section{Data analysis}

The results of antimicrobial susceptibility tests were interpreted with the standards of the French Society of Microbiology. Microsoft Excel 2013 Spreadsheet has been used for data processing and the statistical analysis was conducted using GraphPad Prism 5. The statistical analysis was run at $95 \%$ confidence limit; two tailed test and $p<0.05$ were considered as significant. 


\section{Results}

\section{$E$. coli strains isolated and penicillinase detection}

About $10.32 \%$ of the 979 urine samples analyzed were contaminated by $E$. coli strains. Our data reveals that $60 \%$ of patients with urinary tract infection due to $E$. coli were female. Among the patients with urinary infection due $E$. coli, non-hospitalized patients represented $69.31 \%$. But the difference of proportion between the two groups of patients (hospitalized patients and non-hospitalized patients) was significant $(p>0.05)$. Among the eighty $E$. coli strains $(79.21 \%)$ producing penicillinase, $54(67.5 \%)$ were isolated from non-hospitalized patients. The statistical analysis reveals that the presence of $E$. coli strains producing penicillinase is not function of the patient (in or out) origin $(p>0.05)$.

\section{Extended Spectrum $\beta$-Lactamase (ESBL) production by $E$. coli strains isolated}

The extended-spectrum $\beta$-lactamase (ESBL) was produced by $20 \%$ of isolated strains. Seventy percent $(70 \%)$ of these strains were isolated from non-hospitalized patients. Twenty (20) of 80 strains producer of penicillinase were ESBL. About $80 \%$ of these ESBL were isolated from non-hospitalized patients against $20 \%$ isolated from hospitalized patients. The data indicate that no hospitalized patients carried more ESBL than hospitalized patients ( $p$ $<0.05)$.

\section{Antibiotics resistance of isolated strains}

Our susceptibility test data displays a variability of isolated $E$. coli strains according to tested antibiotic (Table 2). More than $50 \%$ of the E. coli strains were resistant to new antibiotics (amoxicillin, amoxicillin+clavulanic acid, cefuroxime, nalidixic, ciprofloxacin, ofloxacin, norfloxacin, chloramphenicol and trimethoprim sulfa). In addition, high resistance was observed with amoxicillin $(96.75 \%)$ and trimethoprim sulfa $(93.37 \%)$, while the most effective antibiotic was Imipenem with less than $1 \%$ of resistant strains.

Among E. coli strains, there was a variation of the resistance depending on the antibiotic tested considering their ability to produce or not penicillinase (Table 2). However, the recorded differences of resistance proportions were not significant independently to the tested molecule $(p>$ $0.05)$. It should be noted that the high amoxicillin resistance was recorded on both penicillinase producing strains $(92.96 \%)$ than non-producing $(100 \%)$. Only strains resistant to imipenem were penicillinase producers and not extended spectrum $\beta$-lactamases producers.

The strain's resistance profile is highly variable according to antibiotics when we consider the extended spectrum $\beta$-lactamase production 
character $(p<0.0001)$. Globally, the highest proportions of the strains resistant to $\beta$-lactam antibiotics (cefotaxime, amoxicillin, and ceftriaxone) and quinolones (ciprofloxacin, norfloxacin and ofloxacin) were observed with the strains of ESBL-producing E. coli (Table 2).

Table 2: Resistance to antibiotics profile of Escherichia coli strains isolated from urinary tract infections.

\begin{tabular}{|c|c|c|c|c|c|}
\hline & \multicolumn{5}{|c|}{ Resistance rate (\%) } \\
\hline EC $(\mathrm{n}=101)$ & $\begin{array}{c}\text { EC- ESBL } \\
+(\mathrm{n}=20)\end{array}$ & $\begin{array}{c}\text { EC- ESBL } \\
(\mathrm{n}=81)\end{array}$ & $\begin{array}{c}\text { EC-Péni }+ \\
(\mathrm{n}=80)\end{array}$ & $\begin{array}{c}\text { EC-Péni - } \\
(\mathrm{n}=21)\end{array}$ \\
\hline Net & 44 & 100 & 30 & 44 & 50 \\
\hline NA & 69.75 & 100 & 64.81 & 60.61 & 70 \\
\hline AMX & 96.75 & 100 & 93.85 & 92.96 & 100 \\
\hline AMC & 67.33 & 84.21 & 63.23 & 74.32 & 23.07 \\
\hline FOX & 25.58 & 31.25 & 21.15 & 22.41 & 30 \\
\hline CTX & 32 & 100 & 12.86 & 30.67 & 35.71 \\
\hline CXM & 53.72 & 100 & 43.55 & 56.52 & 50 \\
\hline CIP & 51.03 & 94.74 & 40 & 54.28 & 50 \\
\hline OFX & 67.79 & 100 & 59.18 & 69.09 & 80 \\
\hline GM & 41.65 & 84.21 & 28.78 & 40.84 & 42.86 \\
\hline NOR & 60.37 & 94.12 & 53.45 & 64.61 & 45.45 \\
\hline IPM & 1 & 0 & 1.43 & 1.33 & 0 \\
\hline CRO & 33 & 100 & 14.28 & 33.33 & 28.57 \\
\hline FT & 15.15 & 26.31 & 13.04 & 14.67 & 21.43 \\
\hline SXT & 93.37 & 100 & 88.09 & 86.05 & 71.43 \\
\hline C & 66.89 & 66.67 & 61.4 & 58.73 & 77.78 \\
\hline A.
\end{tabular}

Amoxicillin (AMX), amoxicillin/clavulanic acid (AMC), cefoxitin (FOX), cefuroxime (CXM), cefotaxime (CTX), ceftriaxone (CRO), imipenem (IPM), gentamicin (GM), netilmicin (NET), chloramphenicol (C), nalidixic acid, (NA), norfloxacin (NOR), ofloxacin (OFX), ciprofloxacin (CIP), trimethoprim/ sulfamethoxazole (SXT) and nitrofurantoin (FT), EC (Echerichia coli strains), EC- ESBL + (ESBLs producer Echerichia coli strains), ECESBL- ( not ESBLs producer Echerichia coli strains), EC Péni + (Penicillinase producer Echerichia coli strains), EC Péni- (not penicillinase producer Echerichia coli strains).

\section{Presence of gene encoding for Extended Spectrum $\beta$-Lactamase (ESBL)}

The genes (bla TEM and blaSHV) encoding for ESBL production by $E$. coli strains isolated from urinary tract infections were found in various proportions. Thus, our data reveal that all phenotypically ESBL-producer

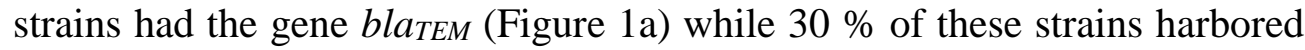
the bla $a_{S H V}$ gene (Figure 1b). 


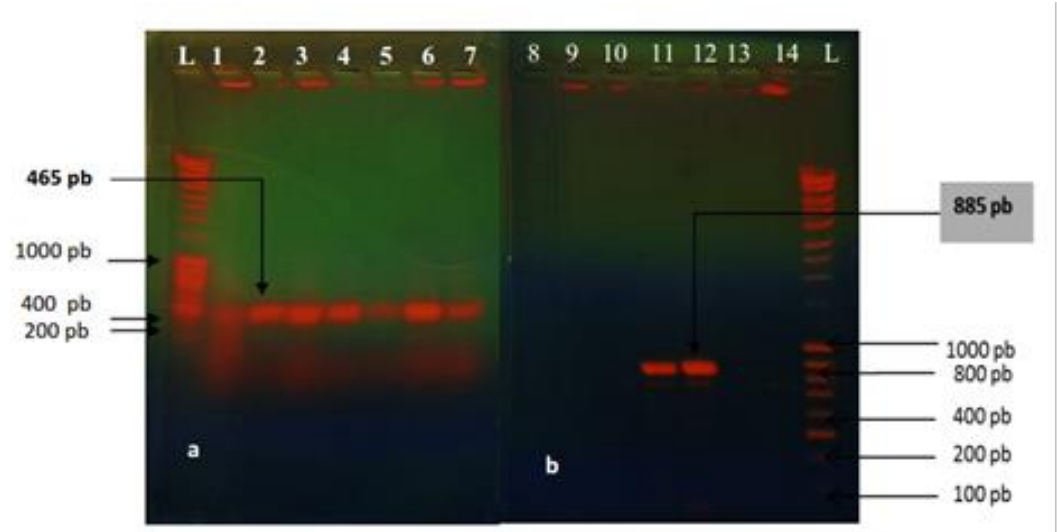

Legend: - lane 1-7: $b l a_{T E M}$ positive samples;

- lane 8: negative control;

- $\quad$ lane 9, 10, 13 and 14: negative samples bla ${ }_{S H V}$;

- lane 11, 12 positive samples bla

- lane L: ladder.

Figure 1: Agarose gel showing polymerase chain reaction amplified product of $b l a_{T E M}$ (a) and bla $_{S H V}(\mathrm{~b})$ genes.

\section{Discussion}

We found a prevalence of $10.32 \%$ for the strains of E. coli isolated from urine samples collected from both hospitalized patient and nonhospitalized patient referred to National and University Hospital Center Hubert Koutoukou Manga. The frequency of urinary E. coli infections is higher in female patients $(59.41 \%)$ than in men. The same tendency was observed in Morocco though their recorded prevalence $(75 \%)$ is higher than ours (Fatna et al., 2009). This is explained the small distance of the female urethra and the promoting sex on the growth of bacteria in the bladder urethral (Beutin et al., 1997).

The phenotypic detection of Extended Spectrum $\beta$-Lactamase (ESBL) showed that the prevalence of $E$. coli ESBL producer isolated from urinary tract infections was $20 \%$. Majority of those strains (70\%) were isolated from non-hospitalized patients. Our results are relatively higher than the $10 \%$ isolated from urinary tract infections in developed country such as America (Galles et al., 2002). This different observed can be due to the fact that in developing countries, the health care system is more organized than low incoming countries such as Benin and the use of drugs such as antimicrobials under medical prescriptions. Even in developing countries such as Yaoundé in Cameroon (Gangoué-Piéboji et al., 2005) and Departmental Hospital Center of Zou-Collines in Benin (Ahoyo et al., 2007), a rate of $14.3 \%$ and 22 $\%$ were respectively reported. Although, our results are similar to those reported in North Africa (Winokur et al., 2001). Indeed, the work of Abbassi et al. (2010) in Tunisia founded $67.7 \%$ E. coli ESBL from community 
patients. The Enterobacteriaceae strains producing ESBL were more often founded in hospitals (Winokur et al., 2001). But we nowadays mostly recorded an increase of $E$. coli ESBL strains isolated from outpatient (Younes et al., 2011; Lonchel et al., 2012).

Globally, E. coli strains isolated from urinary tract infections were highly $(96.75 \%)$ resistant to amoxicillin. This percentage is higher than those obtains in developed countries like France (Golstein, 2000) and United State of America (Mathai et al., 2001). In developing countries like Dakar, high resistance level to antibiotics was observed (Seck, 2005). The drug resulting from the association amoxicillin+clavulanic acid was not efficient on $E$. coli strains isolated from urinary tract infections (61.33\% of resistance). These observations remain bigger than the $40 \%$ of resistant strains recorded in France (Golstein, 2000). The resistance rate (33\%) obtained in this study with ceftriaxone is higher than the $5 \%$ observed in Morocco (Fatna et al., 2009) and lower than the $43.38 \%$ previously founded in Benin (Ahoyo et al., 2007). Thirty-two percent (32\%) of strains isolated were resistance to cefotaxime. This resistance percentage is higher than the $3.7 \%$ to $8.8 \%$ obtained respectively in United States of America (Mathai et al., 2001) and Senegal (Lemort et al., 2006). Relatively, there are high proportions of resistance with nalidixic acid (69.75\%), ofloxacin (67.79\%) ciprofloxacin (51.03\%), trimethoprim/sulphamid $(93.37 \%)$ and chloramphenicol $(66.89 \%)$. The increase of these resistance levels in developing countries can be attributed to many factors such as the poor quality of drugs and/or inadequate dosage, long-term treatment, misuse of antibiotics by health professionals and poor sanitation (Tandé et al., 2012). The misuse and often uncontrolled antibiotic self-medication are addition selection pressure to select resistance strains in bacteria. In a previous study, Van der Starre et al. (2010) had found that all $E$. coli strains isolated from urinary tract infections patients who were treated inappropriately with ciprofloxacin, were resistant to ciprofloxacin. In addition, Wang et al. (2009) have found that the E. coli strains isolated from Respiratory Tract Infections samples were resistant to ciprofloxacin $(71.8 \%)$ and ofloxacin $(63.8 \%)$. In fact, many cases of multidrug-resistant bacteria have been reported in Benin (Sina et al., 2011), Ivory Coast (Akoua-Koffi et al., 2004) and in other sub-Saharan Africa countries (Akinyemi et al., 2005). All E. coli ESBL strains isolated in this study were resistant to amoxicillin, cefotaxime and ceftriaxone. The emergence of producing Enterobacteria ESBL is reported to be a major problem in the treatment of nosocomial infections (Camara et al., 2013).

Among the 16 tested antibiotics, the most efficient was imipenem and more than $99 \%$ of $E$. coli strains isolated were sensitive. These results can be explained by the fact that this antibiotic is a $\beta$-lactam class of carbapenem. This class is known to be resistant to $\beta$-lactamases (carbapenemases) 
hydrolysis (Therrien, 1998). In addition, imipenem is the most sensitive carbapenem for the detection of carbapenemases strains producers (Dahmen et al., 2012). However, some cases of resistance to imipenem had recently been described (Lee et al., 2012; Dash et al., 2013). The strains resistance to nitofurantoïn was low $(15.15 \%)$. This result is higher than $9.8 \%$ obtained at India (Ferron, 1994) on E. coli strains isolated from urinary tract infections. These results confirm the effectiveness of this antibiotic in urinary infections treatment (McOsker et Fitzpatrick, 1994). The Nitrofurantoin is indicated only for the treatment of acute cystitis. The therapeutic doses have a bactericidal activity against $E$. coli isolated from urine (Hooper, 2000; Calbo et al., 2006). The resistances observe in our study may be due to the increases production of penicillinase and extended-spectrum $\beta$-lactamases.

The research of genes encoding for ESBL production on $E$. coli strains reveals that blaTEM gene was carried by all strains but only $30 \%$ harbored $b l a_{S H V}$ gene. Our results are higher than $60 \%$ of $b l a_{T E M}$ reported in Spain (Sanders et Sanders, 1992). These results confirm those of the susceptibility testing displaying that all $E$. coli strains were resistant to penicillinase and third generation cephalosporins (cefoxitin, cefuroxime, cefotaxime and ceftriaxone) (Livermore, 1995). In other cases, the results of Ahoyo et al. (2007) displays $25 \%$ strains carrying the gene bla $a_{\mathrm{TEM}}$ and $56.25 \%$ also harbored the $b l a_{S H V}$ gene. African strains possess bla $a_{\mathrm{SHV}}$ gene (GangouéPiéboji et al., 2005) and the strains producing ESBL currently have genetic mutation of $\beta$-lactamases (TEM and SHV) (Rakotonirina et al., 2013; Philippon, 2013).

\section{Conclusion}

Urinary tract infections are major public health problem. The study updates the information about $E$. coli strains isolated from urinary tract infections in Benin. Our data reveals high prevalence of multidrug-resistant E. coli strains producing ESBL among no hospitalized patients. Thus, it is necessary to avoid prescribing antimicrobial agent treatment to patients before pathogen agent identification. The study took into account only strains isolated from urinary tract infections. It will be important to extend future studies on $E$. coli strains isolated from other samples.

\section{References:}

1. Abbassi, M. S., Ruiz, E., Saenz, Y., Mechergui, A., Ben Hassen, A., \& Torres, C. (2010). Genetic background of quinolones resistance in CTX-M-15-producing Klebsiella pneumonia and Escherichia coli strains in Tunisia. J. Chemother, 22, 66-67. 
2. Ahmad, I., \& Beg, A. Z. (2001). Antimicrobial and phytochemical studies on 45 Indian medicinal plants against multi-drug resistant human pathogens. Journal of ethnopharmacology, 74(2), 113-123.

3. Ahoyo, A. T., Baba-Moussa, L., Anago, A. E., Avogbe, P., Missihoun, T. D., Loko, F., ... \& Dramane, K. (2007). Incidence d'infections liées à Escherichia coli producteur de bêta lactamase à spectre élargi au Centre hospitalier départemental du Zou et Collines au Bénin. Médecine et maladies infectieuses, 37(11), 746-752.

4. Akinyemi, K. O., Oladapo, O., Okwara, C. E., Ibe, C. C., \& Fasure, K. A. (2005). Screening of crude extracts of six medicinal plants used in South-West Nigerian unorthodox medicine for anti-methicillin resistant Staphylococcus aureus activity. BMC complementary and alternative medicine, 5(1), 6.

5. Akoua-Koffi, C., Guessennd, N., Gbonon, V., Faye-Ketté, H., \& Dosso, M. (2004). La méticillino-résistance de Staphylococcus aureus isolés à Abidjan (1998-2001): un nouveau problème en milieu hospitalier. Médecine et maladies infectieuses, 34(3), 132-136.

6. Beutin, L., Gleier, K., Kontny, I., Echeverria, P., \& Scheutz, F. (1997). Origin and characteristics of enteroinvasive strains of Escherichia coli (EIEC) isolated in Germany. Epidemiology \& Infection, 118(3), 199205.

7. Bois, S. D., Marriott, M. S., \& Amyes, S. G. B. (1995). TEM-and SHV-derived extended-spectrum $\beta$-lactamases: relationship between selection, structure and function. Journal of Antimicrobial Chemotherapy, 35(1), 7-22.

8. Bourjilat, F., Dersi, N., Bouchrif, B., Amarouch, H., \& Timinouni, M. (2009). Profil de résistance aux antibiotiques des Escherichia coli uropathogènes communautaires au Maroc. Eur J Sci Res, 38(1), 57-62.

9. Bush, K., Courvalin, P., Dantas, G., Davies, J., Eisenstein, B., \& Huovinen, P. (2011). Tackling antibiotic resistance. Nature Reviews Microbiology, 9(12), 894-896.

10. Bush, K., Jacoby, G. A., \& Medeiros, A. A. (1995). A functional classification scheme for beta-lactamases and its correlation with molecular structure. Antimicrobial agents and chemotherapy, 39(6), 1211.

11. Calbo, E., Romaní, V., Xercavins, M., Gómez, L., Vidal, C. G., Quintana, S., ... \& Garau, J. (2006). Risk factors for community-onset urinary tract infections due to Escherichia coli harbouring extendedspectrum $\beta$-lactamases. Journal of Antimicrobial Chemotherapy, 57(4), 780-783.

12. Camara, M., Ndiaye, H. D., Diallo, A. B., Karam, F., Mbow, M., Faye, A., ... \& Kane, N. C. T. (2014). Epidémiologie des souches de 
Klebsiella pneumoniae productrices de $\beta$-lactamases à spectre élargi dans un hôpital universitaire au Sénégal, 2011. Revue du CAMES: Science de la santé, 1(2).

13. Carlet, J., Jarlier, V., Harbarth, S., Voss, A., Goossens, H., \& Pittet, D. (2012). Ready for a world without antibiotics? The pensières antibiotic resistance call to action. Antimicrobial Resistance and Infection Control, 1,11 .

14. Carvalho, V. M., Osugui, L., Setzer, A. P., Lopez, R. P., Pestana de Castro, A. F., Irino, K., \& Catão-Dias, J. L. (2012). Characterization of extraintestinal pathogenic Escherichia coli isolated from captive wild felids with bacteremia. Journal of veterinary diagnostic investigation, 24(5), 1014-1016.

15. Catlin, B. W. (1975). Iodometric detection of Haemophilus influenzae beta-lactamase: rapid presumptive test for ampicillin resistance. Antimicrobial Agents and Chemotherapy, 7(3), 265-270.

16. Chauhan, S., Mahawal, B. S., \& Ramola, D. C. (2017). Extended spectrum $\beta$-lactamases in urinary isolates of Escherichia coliprevalence and susceptibility pattern at a tertiary care hospital. International Journal of Research in Medical Sciences, 3(7), 1622-1626.

17. Dahmen, S., Mansour, W., Charfi, K., Boujaafar, N., Arlet, G., \& Bouallègue, O. (2012). Imipenem resistance in Klebsiella pneumoniae is associated to the combination of plasmid-mediated CMY-4 AmpC $\beta$-lactamase and loss of an outer membrane protein. Microbial Drug Resistance, 18(5), 479-483.

18. Dash, M., Padhi, S., Mohanty, I., Panda, P., \& Parida, B. (2013). Antimicrobial resistance in pathogens causing urinary tract infections in a rural community of Odisha, India. Journal of family \& community medicine, 20(1), 20.

19. Edwards, R., \& Greenwood, D. (1992). An investigation of $\beta$ lactamases from clinical isolates of Bacteroides species. Journal of medical microbiology, 36(2), 89-95.

20. Ferron, A. (1994). Bactériologique Médicale: Staphylocoques. C et R. Chapitre 13.

21. Foxman, B. (2002). Epidemiology of urinary tract infections: incidence, morbidity, and economic costs. The American journal of medicine, 113(1), 5-13.

22. Gales, A. C., Sader, H. S., Jones, R. N., \& SENTRY Participants Group. (2002). Urinary tract infection trends in Latin American hospitals: report from the SENTRY antimicrobial surveillance program (1997-2000). Diagnostic microbiology and infectious disease, 44(3), 289-299. 
23. Gangoué-Piéboji, J., Bedenic, B., Koulla-Shiro, S., Randegger, C., Adiogo, D., Ngassam, P., ... \& Hächler, H. (2005). Extendedspectrum- $\beta$-lactamase-producing Enterobacteriaceae in Yaounde, Cameroon. Journal of clinical microbiology, 43(7), 3273-3277.

24. Goldstein, F. W. (2000). Antibiotic susceptibility of bacterial strains isolated from patients with community-acquired urinary tract infections in France. European journal of clinical microbiology and infectious diseases, 19(2), 112-117.

25. Hooper, D.C. (2000).Urinary tract agents: nitrofurantoin and methena mine.In: Mandell, GL, Douglas, RG, Bennett, JE, Dolin, R.(eds). Ma ndell, Douglas, and Bennett's Principlesand Practice of Infectious Dis eases, ed 5 Philadelphia : Churchill Livingstone, 423-8.

26. Jarlier, V., Nicolas, M. H., Fournier, G., \& Philippon, A. (1988). ESBLs conferring transferable resistance to newer $\beta$-lactam agents in Enterobacteriaceae: hospital prevalence and susceptibility patterns. Rev Infect Dis, 10(4), 867-878.

27. Lee, S. H., Kim, J. Y., Lee, G. S., Cheon, S. H., An, Y. J., Jeong, S. H., \& Lee, K. J. (2002). Characterization of bla CMY-11, an AmpCtype plasmid-mediated $\beta$-lactamase gene in a Korean clinical isolate of Escherichia coli. Journal of Antimicrobial Chemotherapy, 49(2), 269273.

28. Lee, S. Y., Park, Y. J., Yu, J. K., Jung, S., Kim, Y., Jeong, S. H., \& Arakawa, Y. (2012). Prevalence of acquired fosfomycin resistance among extended-spectrum $\beta$-lactamase-producing Escherichia coli and Klebsiella pneumoniae clinical isolates in Korea and IS 26composite transposon surrounding fosA3. Journal of Antimicrobial Chemotherapy, 67(12), 2843-2847.

29. Lemort, M. L., Neuville, S., Medus, M., Gueudet, P., Saada, M., Aumaître, H., \& Lecaillon, E. (2006). Évolution comparée de la sensibilité de souches de Escherichia coli isolées d'infections urinaires de patients consultant aux urgences et de patients hospitalisés en 2002 et 2004 à l'hôpital de Perpignan. Pathologie Biologie, 54(8-9), 427430 .

30. Livermore, D. M. (1995). beta-Lactamases in laboratory and clinical resistance. Clinical microbiology reviews, 8(4), 557-584.

31. Livermore, D. M., \& Woodford, N. (2006). The $\beta$-lactamase threat in Enterobacteriaceae, Pseudomonas and Acinetobacter. Trends in microbiology, 14(9), 413-420.

32. Lonchel, C. M., Meex, C., Gangoué-Piéboji, J., Boreux, R., Assoumou, M. C. O., Melin, P., \& De Mol, P. (2012). Proportion of extended-spectrum B-lactamase-producing Enterobacteriaceae in 
community setting in Ngaoundere, Cameroon. BMC infectious diseases, 12(1), 53.

33. Lucet, J. C., Chevret, S., Decré, D., Vanjak, D., Macrez, A., Bédos, J. P., ... \& Regnier, B. (1996). Outbreak of multiply resistant Enterobacteriaceae in an intensive care unit: epidemiology and risk factors for acquisition. Clinical infectious diseases, 22(3), 430-436.

34. Maina, D., Revathi, G., \& Whitelaw, A. C. (2017). Molecular characterization of multidrug-resistant Klebsiella pneumoniae and Escherichia coli harbouring extended spectrum beta-lactamases and carbapenemases genes at a tertiary hospital, Kenya. Microbiologia Medica, 32(4).

35. Mathai, D., Jones, R. N., \& Pfaller, M. A. (2001). Epidemiology and frequency of resistance among pathogens causing urinary tract infections in 1,510 hospitalized patients: a report from the SENTRY Antimicrobial Surveillance Program (North America). Diagnostic microbiology and infectious disease, 40(3), 129-136.

36. McOsker, C. C., \& Fitzpatrick, P. M. (1994). Nitrofurantoin: mechanism of action and implications for resistance development in common uropathogens. Journal of antimicrobial chemotherapy, 33(suppl_A), 23-30.

37. Medeiros, A. A. (1997). Evolution and dissemination of $\beta$-lactamases accelerated by generations of $\beta$-lactam antibiotics. Clinical Infectious Diseases, 24(Supplement_1), S19-S45.

38. Paterson, D. L., \& Bonomo, R. A. (2005). Extended-spectrum $\beta$ lactamases: a clinical update. Clinical microbiology reviews, 18(4), 657-686.

39. Philippon, A. (2013). Les bêta-lactamases à spectre élargi ou étendu (BLSE). Immuno-analyse \& Biologie Spécialisée, 28(5-6), 287-296.

40. Pitout, J. (2012). Extraintestinal pathogenic Escherichia coli: a combination of virulence with antibiotic resistance. Frontiers in microbiology, 3, 9.

41. Rakotonirina, H. C., Garin, B., Randrianirina, F., Richard, V., Talarmin, A., \& Arlet, G. (2013). Molecular characterization of multidrug-resistant extended-spectrum $\quad \beta$-lactamase-producing Enterobacteriaceae isolated in Antananarivo, Madagascar. BMC microbiology, 13(1), 85.

42. Riegel, P., Archambaud, M., Clavé, D., \& Vergnaud, M. (2006). Bactérie de culture et d'identification difficiles. Biomérieux, Nancy l'Etoile, France, 119pp.

43. Sanders, C. C., \& Sanders Jr, W. E. (1992). $\beta$-Lactam resistance in gram-negative bacteria: global trends and clinical impact. Clinical Infectious Diseases, 15(5), 824-839. 
44. Seck, R. (2005). Résistance des souches d'Eschérichia coli et de Klebsiella pneumoniae isolées d'infections urinaires. Thèse de pharmacie : Dakar, 41-60.

45. Sina, H., Baba-Moussa, F., Ahoyo, T. A., Mousse, W., Anagonou, S., Gbenou, J. D., ... \& Baba-Moussa, L. (2011). Antibiotic susceptibility and Toxins production of Staphylococcus aureus isolated from clinical samples from Benin. African Journal of Microbiology Research, 5(18), 2797-2803.

46. Singleton, P. E. (1999). Beta lactamase antibiotics", In: "Bacteria in Biology, Biotechnology and Medicine", 4th edition. Chichester, New York, 126.

47. Soussy, C. J. (2015). Comité de l'Antibiogramme de la Société Française de Microbiologie (CASFM): Recommandations 2015. Paris: Société Française de Microbiologie. Retrieved January 10, 2015.

48. Tandé, D., Jallot, N., Bougoudogo, F., Montagnon, T., Gouriou, S., \& Sizun, J. (2009). Extended-spectrum $\beta$-lactamase-producing Enterobacteriaceae in a Malian orphanage. Emerging infectious diseases, 15(3), 472.

49. Therrien, C. (1998). Etude structure-fonction de la B-lactabiase PSE4: inhibition enzymatique et spécificité de substrat. Thèse $P h D$. Université de Laval, Laval, Canada, 118.

50. Van der Starre, W. E., Van Nieuwkoop, C., Paltansing, S., Van't Wout, J. W., Groeneveld, G. H., Becker, M. J., ... \& Leyten, E. M. (2010). Risk factors for fluoroquinolone-resistant Escherichia coli in adults with community-onset febrile urinary tract infection. Journal of Antimicrobial Chemotherapy, 66(3), 650-656.

51. Wang, Y., Zhang, R., Li, W., Feng, Y., \& Leng, T. (2009). Serious antimicrobial resistance status of pathogens causing hospital-acquired lower respiratory tract infections in North China. Journal of international medical research, 37(3), 899-907.

52. Winokur, P. L., Canton, R., Casellas, J. M., \& Legakis, N. (2001). Variations in the prevalence of strains expressing an extendedspectrum $\beta$-lactamase phenotype and characterization of isolates from Europe, the Americas, and the Western Pacific region. Clinical Infectious Diseases, 32(Supplement_2), S94-S103.

53. Younes, A., Hamouda, A., Dave, J., \& Amyes, S. G. B. (2010). Prevalence of transferable bla CTX-M-15 from hospital-and community-acquired Klebsiella pneumoniae isolates in Scotland. Journal of Antimicrobial Chemotherapy, 66(2), 313-318. 